\title{
Robson Haderchpek
}

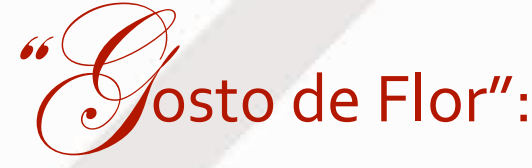

Dramaturgia de imagens e mitologia pessoal no jogo da construção poética

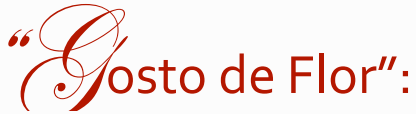

Dramaturgy of images and personal mythology in the play of poetic construction 


\section{RESUMO}

O presente artigo busca analisar a construção dramatúrgica do espetáculo "Gosto de Flor" do Arkhétypos Grupo de Teatro, trazendo para o foco da discussão o conceito de mitologia pessoal e o trabalho de composição a partir de imagens. O referido trabalho foi concebido com base no jogo da construção poética, metodologia desenvolvida pela diretora, bailarina e pesquisadora Lara Rodrigues Machado e teve como ponto de partida uma investigação sobre o amor na perspectiva do universo masculino. Partindo de um processo de criação guiado pelo viés do inconsciente, esta pesquisa teve como principal resultado o espetáculo supracitado.

Palavras-chave: Mitologia Pessoal, Dramaturgia, Jogo da Construção Poética, Processo de Criação, Imagens.

\section{ABSTRACT}

This article seeks to analyze the dramaturgical construction of the play "Gosto de Flor" by the Arkhétypos Theater Group, bringing to the focus of the discussion the concept of personal mythology and the work of composition based on images. This work was conceived based on the play of poetic construction, a methodology developed by the director, dancer and researcher Lara Rodrigues Machado and had as a starting point an investigation about love from the perspective of the male universe. Starting from a creative process guided by the bias of the unconscious, this research had as main result the aforementioned play.

Keywords: Personal Mythology, Dramaturgy, Play of Poetic Construction, Creation Process, Images. 


\section{Introdução}

O espetáculo "Gosto de Flor" é fruto de um trabalho de pesquisa desenvolvido pela diretora Lara Rodrigues Machado ii (UFSB) com os intérpretes-criadores, Allan Phyllipe, Luã Fernandes, Thazio Menezes e Robson Haderchpek, integrantes do Arkhétypos Grupo de Teatro da UFRN iii. O projeto nasceu de uma vontade dos intérpretes de pesquisar o "amor" na perspectiva do masculino iv e fez parte da pesquisa de PósDoutorado da diretora realizada no Programa de Pós-Graduação em Artes Cênicas da UFRN (2016-2017).

"Gosto de Flor" é um espetáculo híbrido, situado entre a dança e o teatro e que tem como foco de sustentação o jogo. O espetáculo fala do encontro entre quatro homens que através da dança narram suas histórias, suas dores, seus desejos, amores e ausências. Num jogo de fragilidades e anseios eles vivem em cena seus excessos e suas faltas. O jogo é desencadeado por uma flor, que é sentida, cheirada, saboreada, compartilhada e dilacerada numa trama de sedução e desejo. O trabalho em si traz provocações acerca do amor e da libido sob o prisma do universo masculino.

O espetáculo estreou no dia 30 de junho de 2017 em Natal/RN e seguiu em temporada se apresentando no Rio de Janeiro/RJ, em Salvador/BA, em Porto Seguro/BA, no México, no interior do Rio Grande do Norte e em alguns Festivais. Depois de dois anos em cartaz o referido trabalho segue reverberando em seus intérpretes e gerando reflexões, tanto no nível artístico como no nível acadêmico.

O processo de criação do espetáculo se deu entre os meses de fevereiro e junho de 2017 e teve como mote principal as memórias pessoais dos intérpretes criadores. Tais memórias foram trabalhadas corporalmente 
através do jogo da construção poética, metodologia de criação cênica desenvolvida pela diretora, bailarina e pesquisadora Lara Rodrigues Machado ao longo de sua carreira. A referida metodologia está explicitada em sua tese de doutorado intitulada O Jogo da Construção Poética: Processo Criativo em Dança (2008).

Trabalhar com as memórias dos intérpretes é um caminho fértil para a construção de uma dramaturgia autoral, ou como diria Inaicyra Falcão dos Santos (2015), de uma dramaturgia pessoal:

A memória aliada à qualidade expressiva do movimento corporal abrange a atenção ao aspecto melódico, ao rítmico, ao impulso, ao jogo, que proferem outras narrativas. Dessa forma, permitem a ressignificação ancestral, no processo transformado em ações vinculadas à história individual, a uma dramaturgia pessoal. (2015, p.81)

As ações trabalhadas no processo de criação do espetáculo "Gosto de Flor" estimularam o inconsciente dos intérpretes-criadores ${ }^{\vee}$ trazendo à tona aspectos simbólicos da sua ancestralidade e da sua mitologia pessoal. A mitologia pessoal está vinculada à história individual do sujeito e originase dos fundamentos do seu ser, refletindo inclusive a mitologia produzida pela cultura na qual este sujeito vive. (FEINSTEIN \& KRIPPNER, 1992). Mais adiante no texto, no tópico Mitologia Pessoal no Espetáculo "Gosto de Flor" voltaremos a abordar essa questão.

Voltando à questão da ancestralidade, no processo de criação do espetáculo "Gosto de Flor", histórias de pais, filhos e netos desencadeavam jogos de carinho, afeto e cuidado, jogos esses que fazem parte da vida, das relações afetivas que cultivamos. Como é sentir a ausência de um pai? Como é projetar essa ausência num amante? Como é abraçar um filho morto pela guerra? Como é não poder abraçar? Como é lidar com um desejo reprimido 
por anos? Perguntas como essas começaram a pulsar no inconsciente de cada intérprete e começaram a tomar forma através do jogo.

As perguntas foram nossos guias dentro deste processo artístico de criação e vale lembrar que a Arte tem uma forma de perguntar que é diferente da Ciência. Verônica Fabrini (2015), pesquisadora das Artes da Cena, entende que tanto a Arte como a Ciência se debruçam sobre as mesmas perguntas, sobre o que é um ser humano, qual a nossa origem, o que é a consciência, ou o que é a finitude. Para Fabrini essas perguntaschave são as perguntas dos mitos, das religiões, da filosofia, da ciência e da arte, e apesar das perguntas serem as mesmas, ela defende que há uma diferença na forma de perguntar:

[...] na ciência, o "como" as coisas funcionam e o "porquê" delas é a pergunta; na arte, a pergunta é "o que é" a coisa, e nesse caso ela deixa a própria coisa falar, pois enquanto na Ciência predomina o pensamento lógico e analítico, na arte o pensamento é analógico - e também sintético, pois mostra concentrações de realidade. Ou ainda como diz Bachelard, o pensamento diurno é predominante na Ciência, ao passo que o pensamento noturno é predominante na Arte, ou ainda, "pensar em animus" (analítico, segmentador, lógico, racional) ou "pensar em anima" (sintético, totalizante, sensível). Bachelard esclarece esses dois tipos de leitura do mundo: em anima - que se detém nas imagens - e em animus - que se atém aos eventos. (FABRNI, in BAPTISTA; SERVERINO; ANDRÉ, 2015, p. 161-162. Grifo nosso).

Como estamos tratando aqui de um processo de criação em Arte e como estamos nos propondo a falar de uma dramaturgia de imagens, permitimo-nos guiar pelo sensível, pelo sintético e pelo totalizante, ou seja, permitimo-nos "pensar em anima". E neste sentido, faz-se mister esclarecer, que não nos interessa a análise semiótica da imagem, não estamos partindo de um pensamento analítico, lógico e racional, preferimos deixar que as imagens falem por si. 
Apesar do espetáculo "Gosto de Flor" trazer provocações acerca do amor e da libido sob o prisma do universo masculino, ele foi "pensado em anima" e traz em si as matizes do pensamento noturno das Artes, deixando falar as imagens que pulsavam em nosso inconsciente.

\title{
Dramaturgia de Imagens no Jogo da Construção Poética
}

Segundo o psiquiatra e psicoterapeuta suiç̧o Carl Gustav Jung (2012), fundador da psicologia arquetípica:

\begin{abstract}
Do inconsciente emanam influências determinantes, as quais, independente da tradição, conferem semelhança a cada indivíduo singular, e até identidade de experiências, bem como da forma de representá-las imaginativamente. Uma das propostas principais disto é o paralelismo quase universal dos motivos mitológicos, que denominei arquétpos, devido à sua natureza primordial. (JUNG, 2012, p. 68)
\end{abstract}

Ao longo do processo de criação do espetáculo "Gosto de Flor" pudemos vivenciar alguns desses motivos mitológicos e acessamos energias arquetípicas que se transmutaram em movimento, fazendo pulsar em nossos corpos histórias de paixão, de dor, rompimentos e desejos:

Hoje eu senti saudade de um amor que já se foi... Meu peito se despetalou, se despedaçou, se transformou em cinzas... cinzas de um amor que foi queimado, que viveu o seu luto... Dói, fica um vazio imenso no peito, um caminhar a esmo, um desejo de ter o que já se foi... o abraço mais perfeito, aquele que junta os pedaços por dentro e que você nunca mais vai receber. (Diário de Bordo, 29 de abril de 2017).

O trecho acima foi escrito após um laboratório de criação realizado com uma flor. Cada intérprete levou para a sala de trabalho uma flor e eu escolhi levar uma rosa vermelha. A rosa sempre me cativou por sua beleza e sua tez aveludada, sem contar o perfume. Contudo, neste dia, após 
termos dançado com as nossas flores, buscamos relacioná-las com uma imagem. Ao longo do processo trabalhamos com dez imagens cada um, e neste dia, a imagem escolhida por mim foi a seguinte:

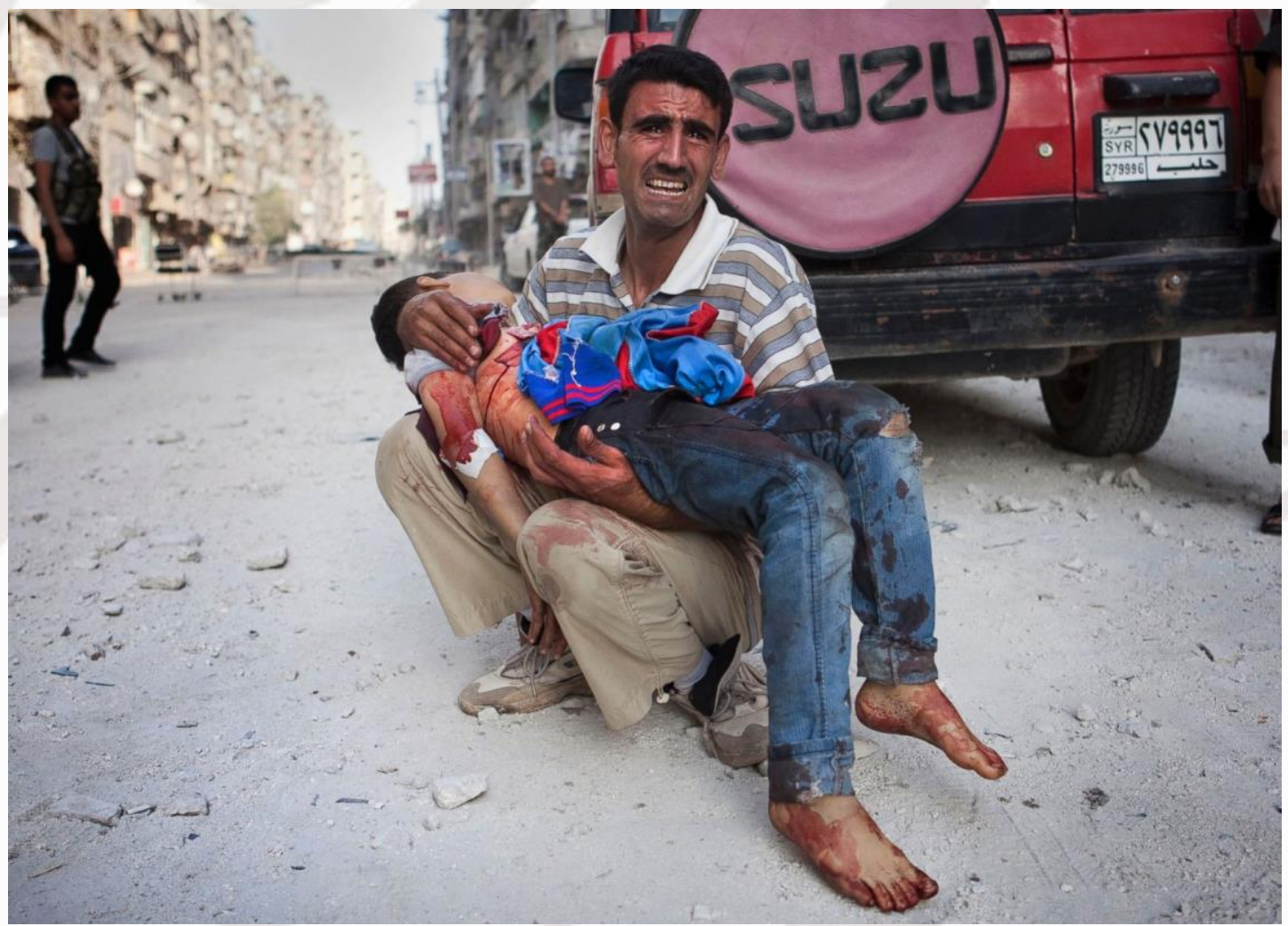

Fig. 1 - Disponível em: http://m.imgur.com/r/HumanPorn/UWft8T5. Acesso em 24 de Abril de 2020.

Esta imagem foi tirada em dezembro de 2014 e traz um recorte cruel da Guerra da Síria, onde um pai traz nos braços a dor de segurar um filho morto. Em nome da liberdade poética, talvez possamos comparar esta imagem à Pietà de Michelangelo (1499), porém, no lugar de uma mulher que chora a morte do filho, temos uma figura masculina. A relação que construí com a referida imagem me trouxe algumas questões e me fez 
pensar: Seriam os homens capazes de amar com tamanha intensidade? Um homem poderia sentir uma dor tão grande?

Sim, enquanto seres humanos todos nós somos capazes de sentir dor e de amar, mas na nossa contemporânea, sustentada por um pensamento machista e patriarcal, é vedado ao homem o direito de expressar suas emoções. O homem não pode sentir dor, não pode demonstrar fraqueza, e por conseguinte, também não pode demonstrar o seu amor.

Após dançar com a minha rosa vermelha naquele laboratório, eu jamais imaginei que iria acessar uma imagem de dor, mas ela saltou do meu inconsciente e se fez carne no jogo da construção poética. Naquele dia, na primeira parte do trabalho a nossa diretora pediu que nós dançássemos com a nossa flor, e assim o fizemos, mas, depois ela pediu que nós escolhêssemos uma imagem que expressasse o que estávamos sentindo em nosso íntimo. Naquele momento eu me fechei para o jogo com os meus companheiros de cena e fiquei no canto da sala dançando sozinho a minha dor. Hoje, refletindo sobre essa situação, posso dizer que estava acessando as raízes da minha mitologia pessoal (FEINSTEIN \& KRIPPNER, 1992).

Quando terminamos o laboratório de criação neste dia eu não conseguia verbalizar o que estava sentindo, por isso escrevi. Em dado momento do processo a minha rosa foi tirada de mim e um sentimento incomensurável de solidão se apoderou do meu ser. A flor vermelha me fez despertar para o vermelho do sangue que escorre nas guerras, me fez despertar para o lado mais doloroso do amor, aquele que se manifesta no momento da perda.

No início do processo, a diretora Lara Machado pediu que cada intérprete-criador escolhesse dez imagens que falassem sobre o amor e as 
levassem para a sala de ensaio. Dentre as minhas imagens, cinco delas falavam de dor, e eu não entendia racionalmente o porquê, mas, naquele dia, meu corpo me mostrou o caminho. Às vezes o nosso corpo sabe de coisas que a nossa mente faz questão de não ver, talvez para nos poupar, mas aí está a grande importância da arte em nossa sociedade, a arte exprime de forma concreta o nosso universo simbólico.

Por meio de notas musicais, de movimentos corporais, de palavras e ações as artes vão tomando forma e vão revelando histórias, sentimentos adormecidos e diversos outros aspectos do nosso inconsciente. É isso o que acontece, por exemplo, quando se adentra ao jogo da construção poética. Trabalhar com o jogo da construção poética é se desnudar, se expor e deixar o nosso inconsciente falar através do corpo vi, do improviso e da relação com o outro:

Nessa proposta a prática corporal se dá a partir do improviso, das criações e descobertas de movimentos que surgem em processos de diálogos corporais na relação entre os intérpretes, de modo que o jogo entre os corpos é o próprio jogo da construção poética. Para esse relacionamento adotam-se elementos da capoeira e da dança que cada corpo traz consigo. (MACHADO, 2017, p.66. Grifo nosso.)

Todo o processo de criação do espetáculo "Gosto de Flor" foi conduzido por estes princípios. Sempre iniciávamos o trabalho gingando e trabalhando elementos do jogo da capoeiravii, depois partíamos para uma série de jogos que se estabeleciam em função da relação construída entre os corpos dos intérpretes-criadores. Segundo Lara Machado: "O jogo pode também ser tomado como a relação entre o corpo do intérprete e outro 
estímulo qualquer [...], entre uma pessoa e determinado elemento cênico ou entre um corpo e uma imagem" (MACHADO, 2017, p.66).

O nosso jogo se dava na relação direta com o outro, mas nós tínhamos as imagens como um referencial, e a cada dia elas nos influenciavam de uma maneira diferente. Houve momentos em que escolhemos uma imagem e dançamos a partir dela e/ou com ela. Houve dias em que contemplamos todas as imagens e simplesmente jogamos, deixando que elas se manifestassem em nossas corpos. Houve momentos também em que dançamos sem as imagens e ainda sim elas estavam lá, presentes no nosso jogo.

As imagens são canais de manifestação do nosso inconsciente, elas falam diretamente aos nossos sentidos nos revelando o seu caráter oculto. Segundo Gilbert Durand (1998), estudioso das teorias do imaginário:

Qualquer manifestação da imagem representa uma espécie de intermediário entre um inconsciente não manifesto e uma tomada de consciência ativa. Daí ela possuir o status de símbolo e construir o modelo de um pensamento indireto no qual um significante ativo remete a um significado obscuro. (p.36. Grifo nosso)

Foi exatamente isso o que aconteceu no processo de criação do espetáculo "Gosto de Flor", as imagens, escolhidas por cada intérprete, começaram a revelar o seu significado obscuro viii, trazendo à luz o que estava por trás de cada uma delas, e no meu caso, elas revelaram uma dor oculta: "Para Jung, a imagem, por sua própria construção, é um modelo de autoconstrução (ou individuação) da psique." (DURAND, 1998, p.37).

Durand (1998) dialoga com Jung (2012) quando afirma que a imagem é um modelo de autoconstrução da psique, e tomando como 
referência o processo de criação supracitado, eu posso dizer, enquanto intérprete-criador, que vivi essa autoconstrução através do jogo da construção poética.

No final de 2015 eu havia terminado um relacionamento amoroso que deixou uma ferida profunda em minha psique. Eu havia amado uma pessoa de um modo tão intenso que fiquei sem chão ao vê-la partir. Foi como se algo muito precioso tivesse sido tirado de mim, foi como se eu fosse aquela rosa vermelha que sangrava, a rosa que me foi roubada/arrancada durante o jogo, por isso, a relação com a imagem da guerra.

Inconscientemente eu ainda sangrava por dentro, mesmo me dispondo a viver uma nova história de amor. Eu demorei para perceber isso, mas havia uma ferida aberta em minha psique que precisava ser curada e ela se manifestou no jogo com as imagens. Segundo Durand:

Os doentes com perspectiva de cura têm sonhos espontâneos ou desenham círculos quadrangulados como aqueles usados nas meditações do budismo tibetano (mandalas). Portanto, de alguma forma, a imagem representa um "sintoma ao contrário" e um indicador de boa saúde psíquica. (DURAND, 1998, p.37).

No trecho citado anteriormente, Durand faz alusão ao processo de autoconstrução (ou individuação) proposto por Jung. É como se dentro do processo de criação nós tivéssemos oportunidade de viver um "sonho acordado", desenvolvendo o que Jung (2012) chamou de "imaginação ativa", para ele:

As fontes oníricas são muitas vezes instintos reprimidos, cuja tendência natural é influenciar a mente consciente. Em casos desse tipo entregamos ao paciente a tarefa de contemplar cada fragmento de sua fantasia que lhe parece importante dentro do 
seu contexto, isto é, examinando-o à luz do material associativo em que está contido, até poder compreendê-lo. (2012, p.58).

Na tentativa de falar de amor eu me deparei com a dor que habitava o meu inconsciente e a projetei no jogo da cena, na relação com os meus companheiros. Neste dia de laboratório eu me lembro que todos depositamos as nossas flores num vaso cheio de pedras e ao final eu me dei conta do luto não vivido:

Sim agora eu entendo as flores dos cemitérios, são pedaços de saudades depositados ao vento... Minha flor foi queimada pela guerra, minha flor é vermelha, e queima, e sangra e transborda. É esse o meu abraço perdido, o abraço do nunca mais. (Diário de Bordo, 29 de abril de 2017).

É muito difícil lidar com esse sentimento de perda, e ele estava lá, pulsando em algum lugar do meu inconsciente, sem que eu me desse conta, e o jogo da construção poética o trouxe à luz, projetando-o para fora e tornando-o consciente.

Algum tempo depois, quando passamos a organizar o material cênico, a fim de construir a dramaturgia do espetáculo, eu percebi que a minha cena tinha início dentro de um cemitério, repleto de flores mortas e de pétalas abandonadas. 


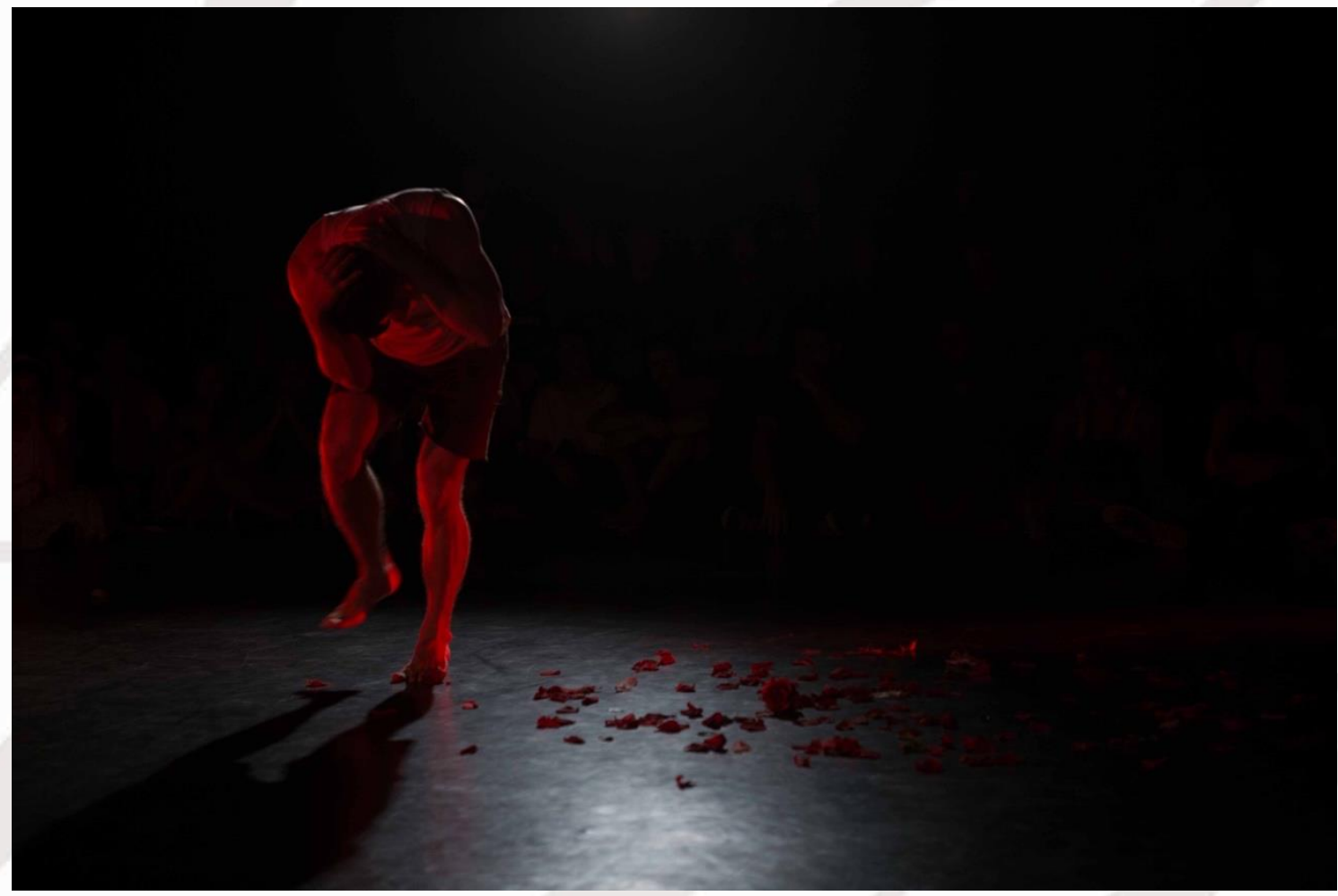

Fig. 2 - Espetáculo "Gosto de Flor", estreia 30 de junho de 2017. Foto: Paulo Fuga.

Na imagem anterior eu danço a dor da perda e finalmente vivo o luto de um amor que foi interrompido. No meio das pétalas abandonadas, no chão de um cemitério imaginário, eu seguro o meu amor nos braços pela última vez, enterrando ali um sentimento que foi gerado, tal como um filho, que foi abatido em meio à guerra, de modo abrupto e inesperado.

Na sequência da cena, em meio a tanta dor eu encontro um respiro... em meio a tantos destroços eu vejo uma flor vermelha e a tiro para dançar, tal como aconteceu no laboratório de criação. Ela me consola, me devolve a vida e eu tento possuí-la, mas a dor que habita o meu ser é maior, e eu preciso me curar para merecer o seu amor.

Mais uma vez as imagens falam por si, e inconscientemente eu estava dando vida a outra figura que escolhi para falar de amor neste 
processo. A imagem a seguir é de uma série americana chamada "The Night

Shift", a cena em questão retrata o amor entre dois homens no momento em que um deles é internado por causa de um tumor.

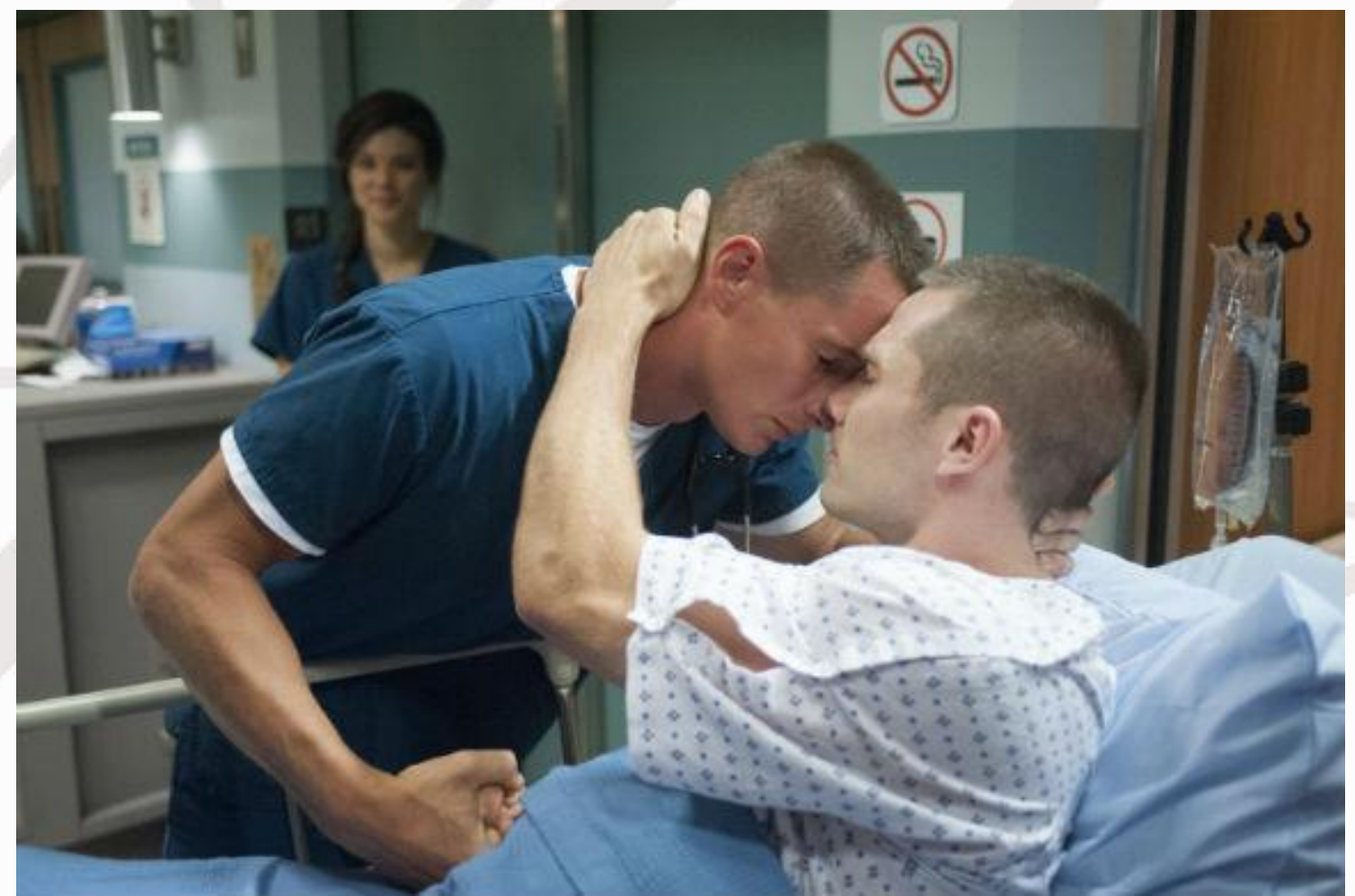

Fig. 3 - Disponivel em: <https://img.huffingtonpost.com/asset/5cd5bad21fo 0005800ge2402.jpeg?ops=scalefit_630_noupscale> Acesso em: 24 de abril de 2020 .

Quando escolhi esta imagem eu vi nela uma conexão que transcende a questão de gênero e nos coloca no lugar do humano, do sensível. Ela também carrega em si, de forma implícita, uma dor, porém, uma dor que é compartilhada. No espetáculo "Gosto de Flor" ela se traduziu assim: 


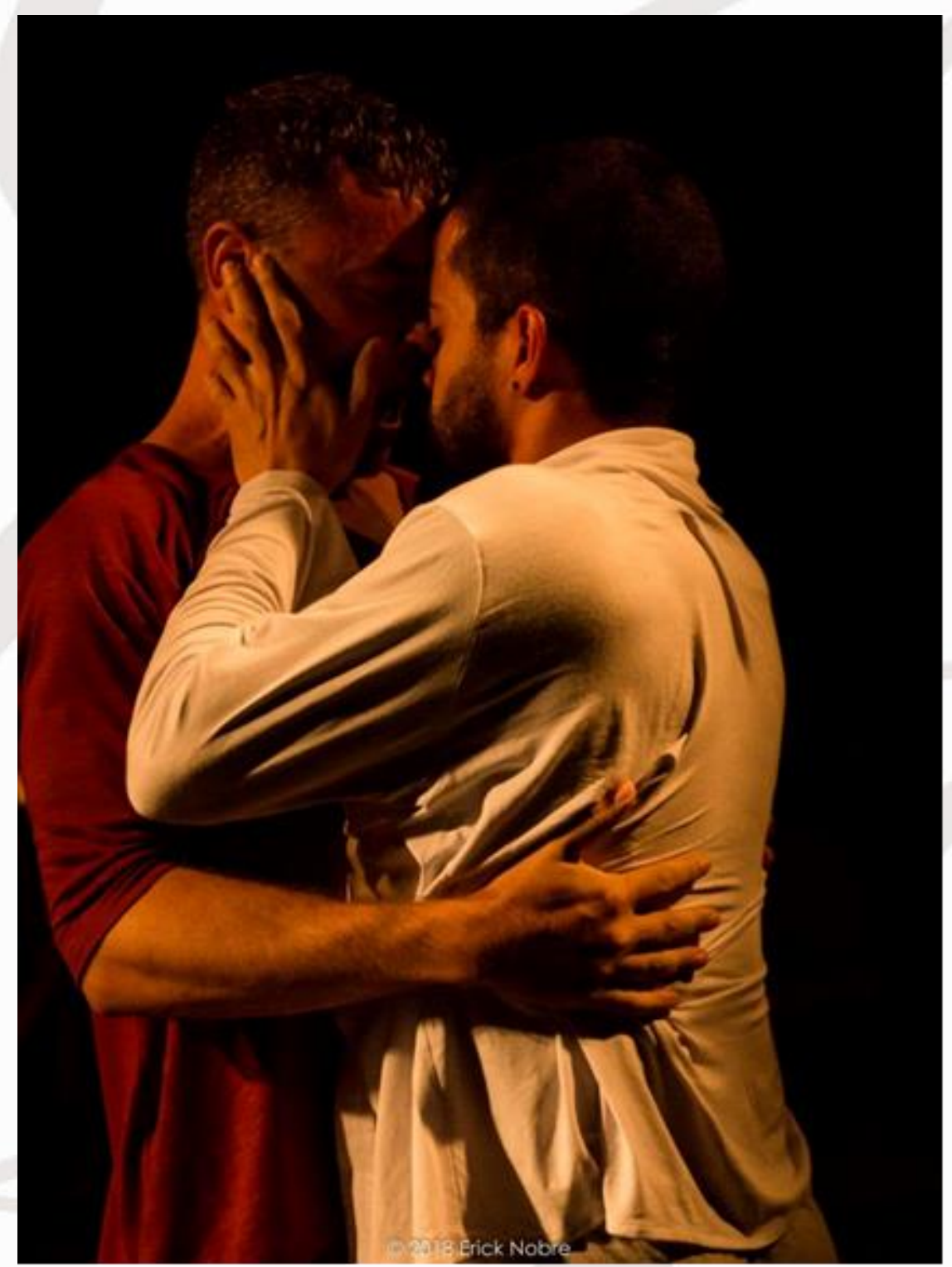

Fig. 4 - Espetáculo "Gosto de Flor". Foto: Erick Nobre.

Dentro da dramaturgia do espetáculo, quando eu me encontro com a figura em questão, ela aparece diante de mim de forma faceira, dançando em meio a cartas rasgadas. Neste momento do jogo eu estou saindo de um relacionamento, tentando deixar para trás o passado que reluta em não ir embora, e então me coloco num dilema, me vejo dividido 
entre dois amores. A figura do presente dança diante de mim como esse amor cúmplice, fiel que vai segurar a minha mão num momento de dor. Mas a figura do passado, me acompanha, como um fantasma, me abraçando por trás e me seduzindo, tal como na imagem a seguir:

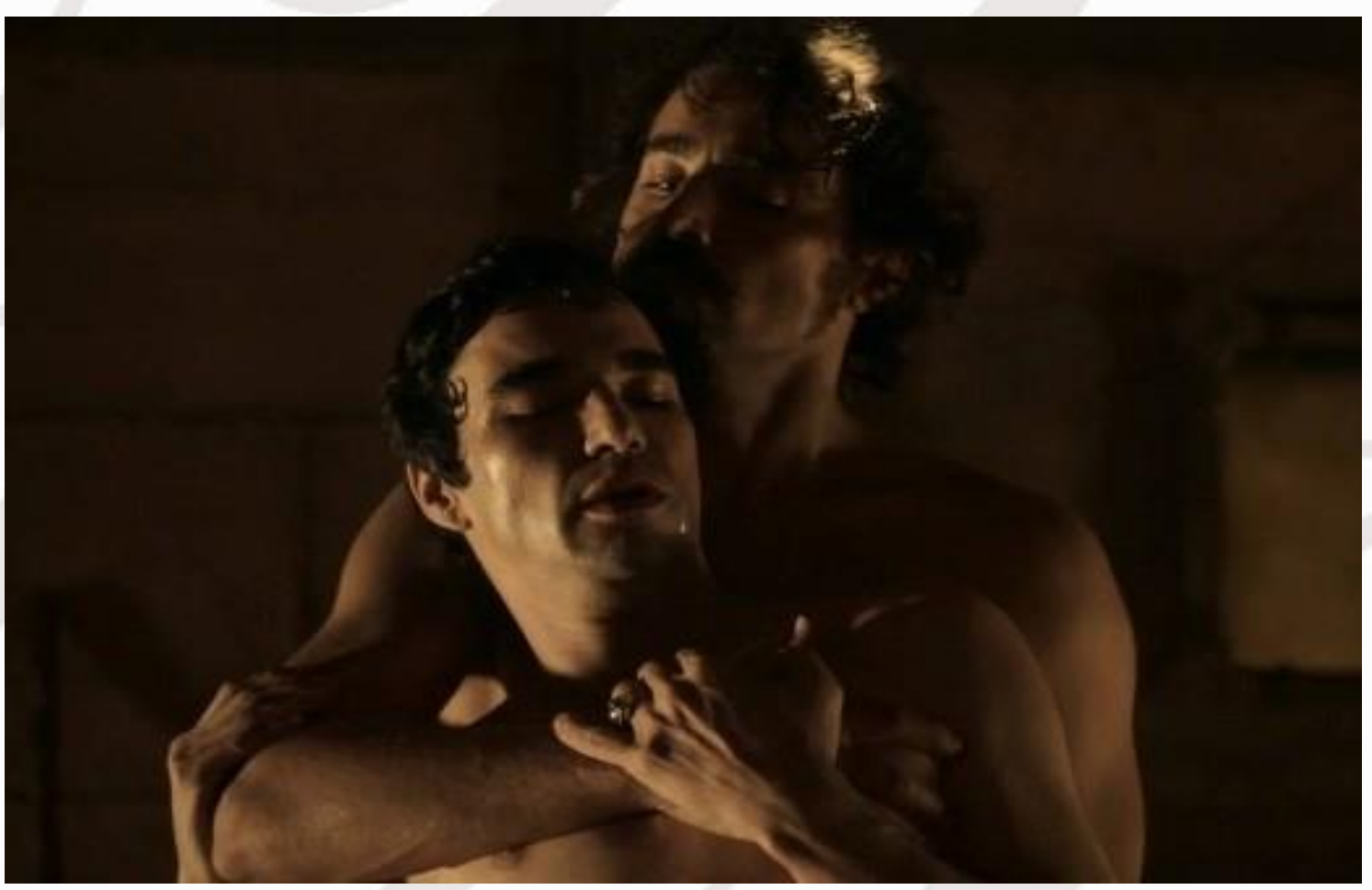

Fig. 5 - Disponivel em: <https://staticr1.blastingcdn.com/media/photogalle ry/2016/7/13/660x29o/b_502×220/cena-gay-exibida-na-novel-da-globo_784573.jpg> Acesso em 24 de abril de 2020.

Esta imagem foi utilizada no processo de criação e fazia alusão a um amor carnal, uma atração física ardente. Na imagem vemos dois homens se abraçando e se entregando ao desejo de modo incontrolável. A cena é de uma novela da rede globo chamada "Liberdade" e foi protagonizada pelos atores Caio Blat e Ricardo Pereira em 2016. No espetáculo "Gosto de Flor" essa relação surgia toda vez que a imagem do passado se aproximava de mim. Eu sempre tentava me desvencilhar dela, 
mas ela me envolvia num jogo de sedução e desejo, tal como um obsessor que insiste em não ir embora.

Na fase dos laboratórios de criação houve um dia em que eu empurrei com toda a força o meu companheiro de cena, tentando fazê-lo ir embora, mas ele permanecia atrás de mim. No espetáculo "Gosto de Flor" a cena transcorreu da seguinte maneira:

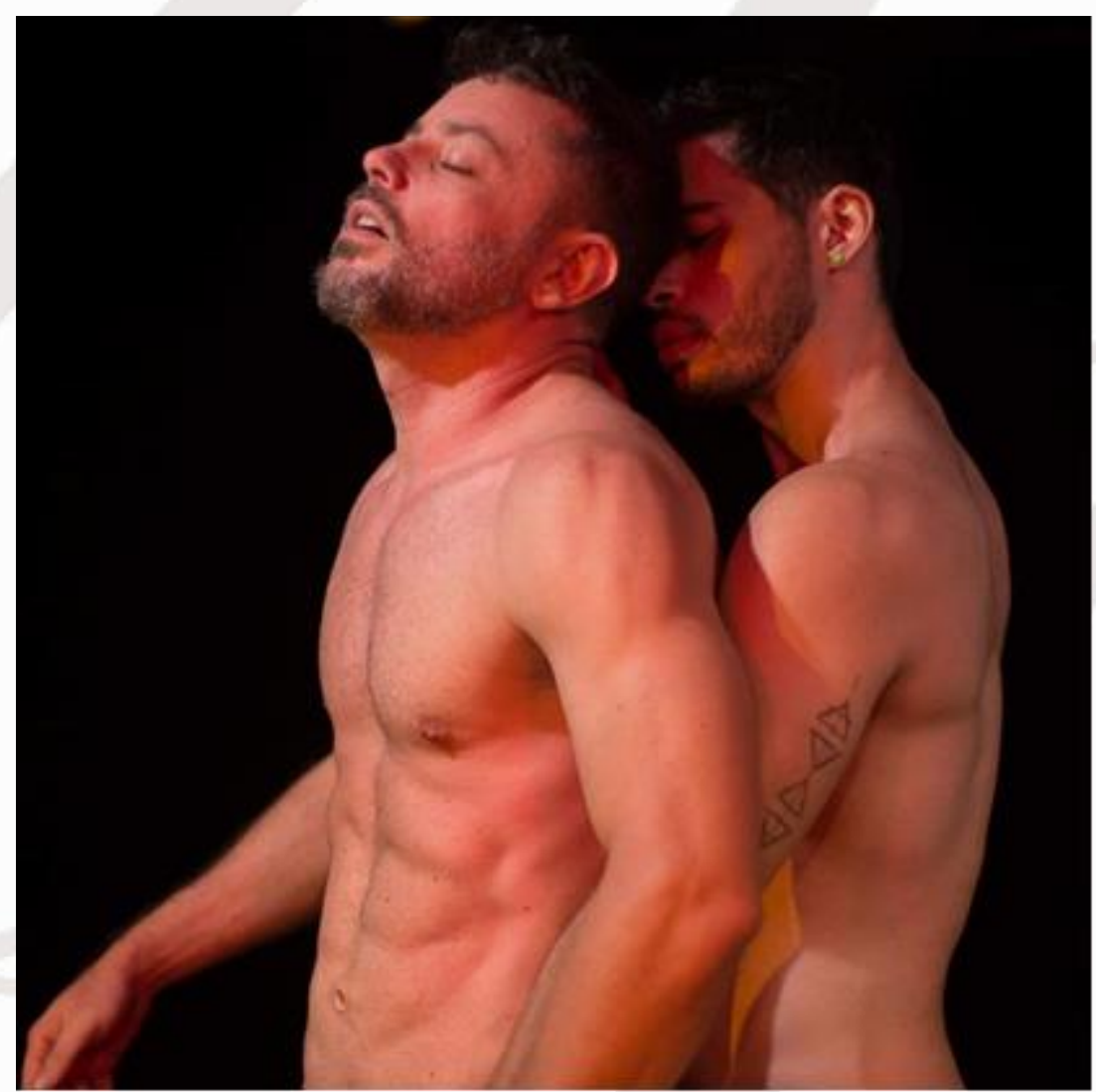

Fig. 6 - Espetáculo "Gosto de Flor", cena da obsessão. Foto: Paulo Fuga.

Dividido entre o amor do presente, cúmplice e fiel e o amor do passado que assombrava o meu inconsciente como um obsessor, eu acabo escolhendo ficar com os dois, e daí surge o triângulo amoroso que vai gerar todo o conflito da dramaturgia. 
A cena em questão surgiu de um jogo proposto pela diretora no dia em que um dos intérpretes-criadores faltou ao ensaio, e então, os três que se fizeram presentes criaram um jogo de quedas e acolhimento. A regra era nunca deixar o terceiro elemento cair, e assim, começou a surgir uma relação tríplice. No começo houve certa hesitação, mas aos poucos os nossos corpos foram se encaixando. Finalizado o laboratório de criação eu pedi à diretora para incorporar mais uma imagem às dez primeiras selecionadas no início do processo, a imagem destacada a seguir:

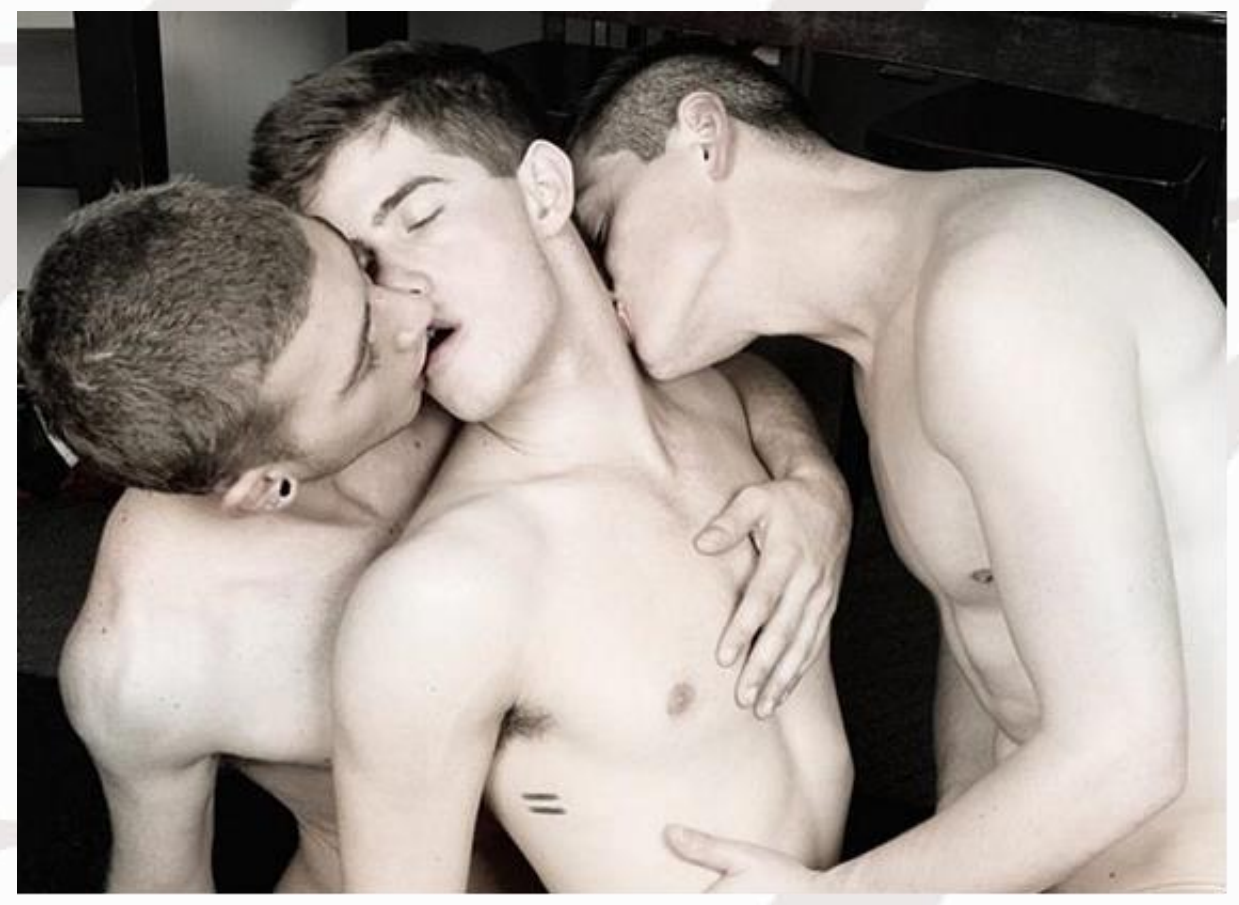

Fig. 7 - Disponivel em: <https://conquistou.com/wp-content/uploads/20 16/08/ tumblr_n5939fwTWE1rxn5t401_1280_640x345_acf_cropped-1.jpg> Acesso em 24 de abril de 2020. 


\section{Mitologia Pessoal no Espetáculo "Gosto de Flor"}

Naquele momento eu percebi que estava colocando em cena a minha mitologia pessoal. Três meses após terminar o meu relacionamento amoroso, sem de fato ter vivido o luto do fim, eu me encantei por uma outra pessoa e comecei uma nova história sem ter finalizado dentro de mim a história anterior. Guiado pelo lado racionalix eu segui adiante, mas o que eu não sabia é que meu lado emocional carregava em si um fantasma do passado, e não me permitia viver integralmente a minha história atual. Segundo Feinstein \& Krippner (1992):

Os mitos, no sentido que damos ao termo, não são lendas ou falsidades, mas modelos através dos quais os seres humanos organizam e codificam suas percepções, sentimentos, pensamentos e atitudes. Sua mitologia pessoal origina-se dos fundamentos do seu ser, sendo também o reflexo da mitologia produzida pela cultura na qual você vive. Todos criamos mitos baseados em fontes que se encontram dentro e fora de nós e nós vivemos segundo esses mitos. (p.16).

Sem perceber eu estava vivendo um triangulo amoroso e tentava equilibrar o passado e o presente dentro de mim, sem obter sucesso. O que acontecia em cena, no jogo da construção poética, era reflexo do meu inconsciente, era uma projeção da minha mitologia pessoal, e na medida que eu tentava me desvencilhar do passado ele me envolvia numa trama de sedução e desejo.

Eu tentava negar o passado dentro de mim, mas ele me seduzia, como um fantasma que não quer deixar a casa assombrada. Ele não era real, mas ele estava lá o tempo todo. Eu estava vivendo um dilema entre um amor real e um amor platônico, e só consegui compreender isso, um ano depois da estreia do espetáculo. 
Nesta cena nossos corpos dançam como se fossem se devorar, como se fossem se tornar um, mas no ápice do jogo aparece um quarto elemento que seduz a todos e nos faz voltar à infância. Criamos então um pega-pega com a flor, e neste momento ela é roubada.

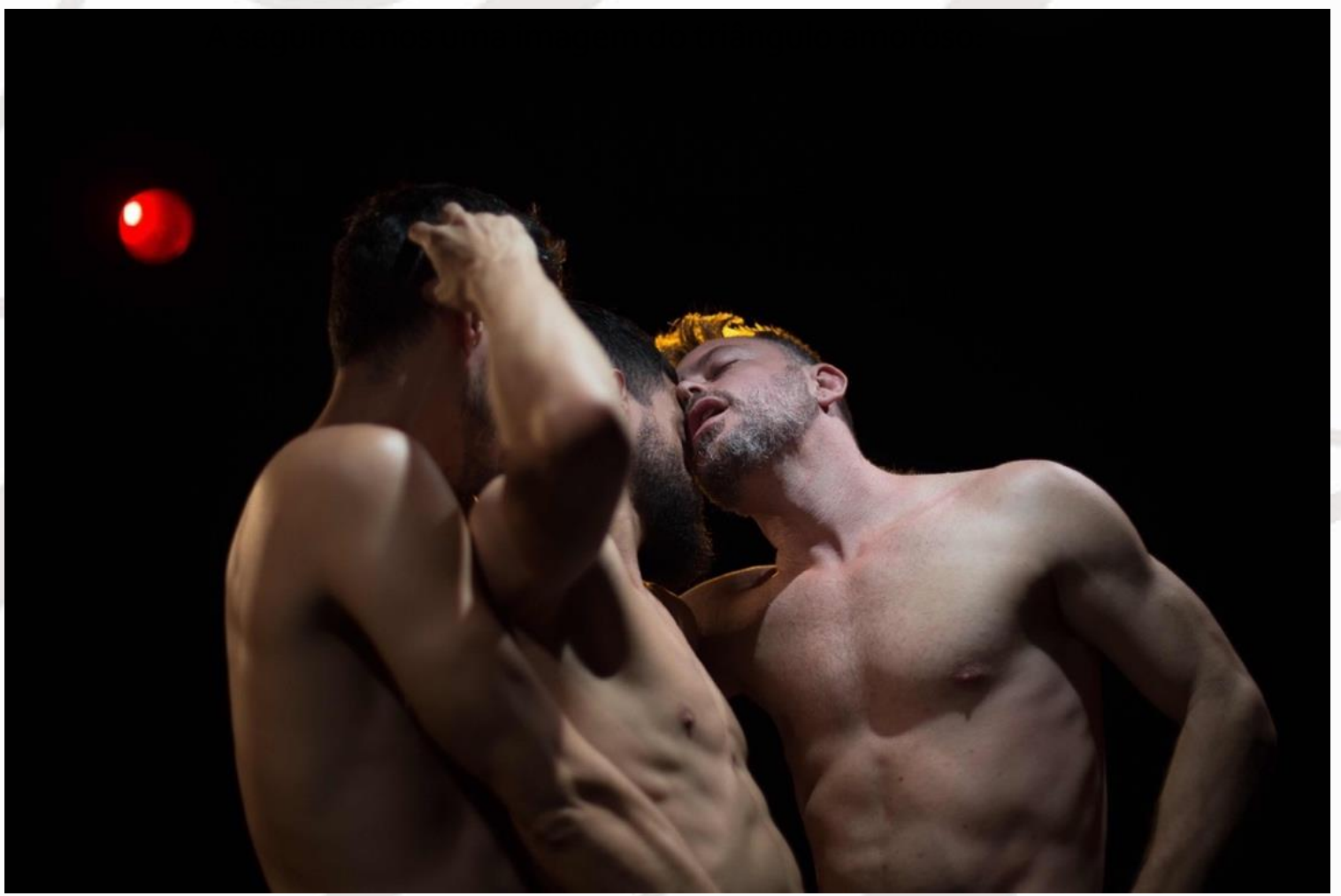

Fig. 8 - Espetáculo "Gosto de Flor", cena do triângulo amoroso. Foto: Paulo Fuga.

Durante o processo de criação, fomos guiados o tempo todo pelas imagens que escolhemos e elas nos ajudaram a organizar a dramaturgia do espetáculo, uma dramaturgia que trazia em si muito daqueles que a tinham construído, uma dramaturgia de imagens. E quando digo imagens, não me refiro somente às imagens materiais, às fotos usadas no âmbito laboratorial, me refiro também às imagens do inconsciente, às imagens que ganharam forma através da nossa imaginação e que se materializaram nas 
relações cênicas, no jogo. E neste sentido, Huizinga, autor do livro Homo Ludens (2007), nos lembra:

\begin{abstract}
O jogo baseia-se na manipulação de certas imagens, numa certa "imaginação" da realidade (ou seja, a transformação desta em imagens); nossa preocupação será, então, captar o valor e o significado dessas imagens e dessa "imaginação". Observamos a ação destas no próprio jogo, procurando assim compreendê-lo como fator cultural da vida. (HUIZINGA, 2007, p.07).
\end{abstract}

Foi isso o que buscamos fazer ao longo do processo de criação do espetáculo "Gosto de Flor", tentamos captar o significado oculto de todas essas imagens deixando que elas falassem através da nossa imaginação e demos corpo a elas, tornando-as vivas, pulsantes. Foi assim que construímos a dramaturgia do espetáculo, uma dramaturgia constituída de imagens. E neste sentido, convém lembrar que quando escolhemos ler o mundo através de imagens estamos "pensando em anima". (FABRNI, in BAPTISTA; SERVERINO; ANDRÉ, 2015).

Se pudermos transformar as imagens do nosso inconsciente em ações físicas, poderemos compreender o sentido delas para a nossa vida, e assim, redimensioná-las a num processo de criação cênico. Trabalhar sob a perspectiva da imagem é tocar as dimensões do inconsciente, é "pensar em anima", é trabalhar como o analógico, com o sensível e fazer da arte um processo de ressignificação simbólico capaz de reorganizar e codificar nossas percepções, sentimentos, pensamentos e atitudes.

Vale salientar que este processo foi vivenciado por quatro intérpretes-criadores e cada qual teve o seu processo individual respeitado, cada qual acessou as suas mitologias pessoais e cada qual fez a leitura das cenas. E neste sentido, podemos dizer que existem várias versões de uma mesma históriax, que é lida e interpretada pelo espectador.

Robson Haderchpek - “Gosto de Flor”: Dramaturgia de Imagens e Mitologia Pessoal no Jogo da Construção Poética 
Ao final do trabalho, a flor, que conduz toda a narrativa do espetáculo é compartilhada pelos quatro intérpretes e dilacerada num jogo de sedução e desejo:

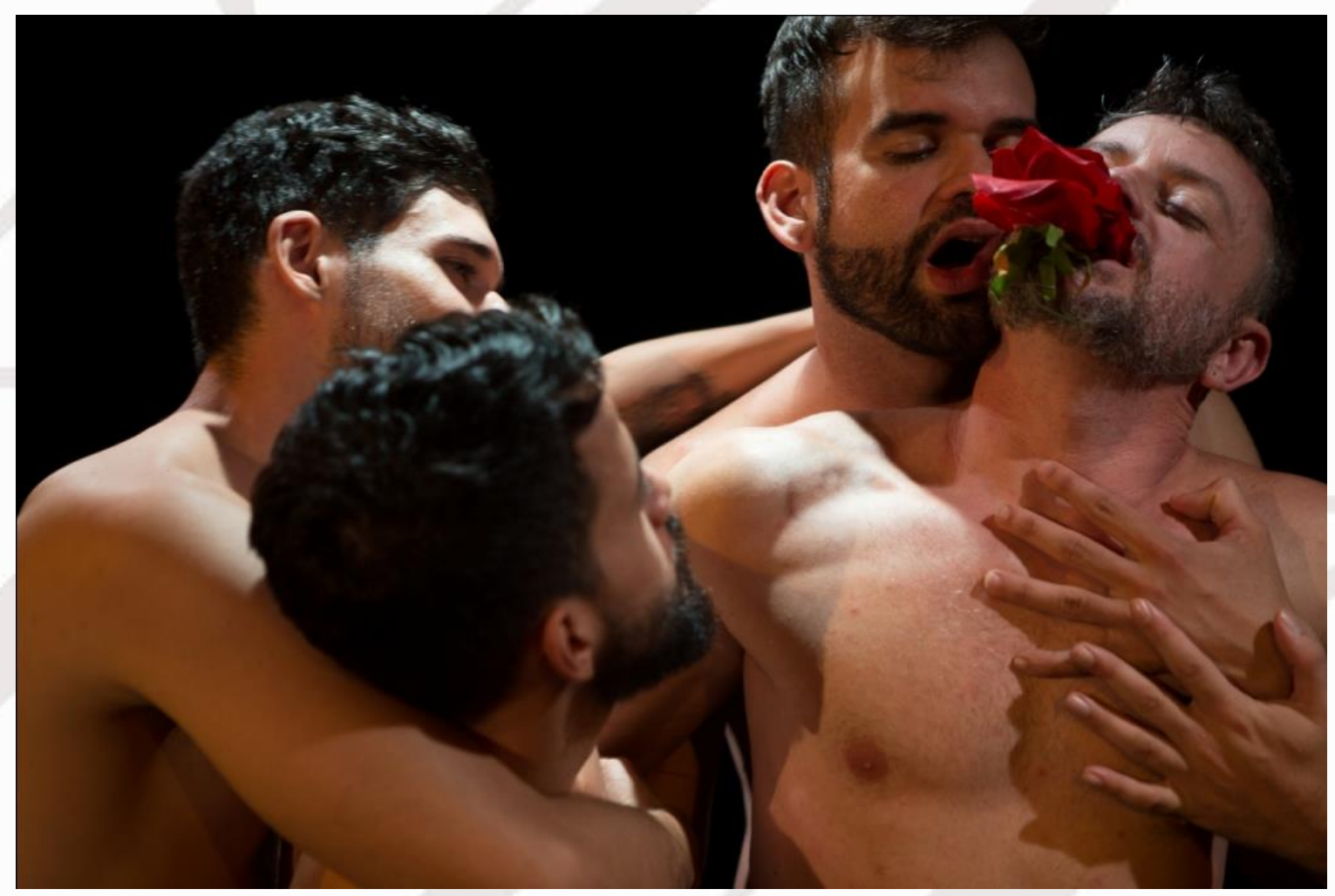

Fig. 9 - Espetáculo "Gosto de Flor", cena final. Foto: Paulo Fuga.

\section{Considerações Finais}

Na tentativa de pesquisar o "amor" sob a perspectiva do universo masculino e descontruir essa visão machista de que o homem não tem sentimentos mergulhamos em nossas próprias histórias e trouxemos à tona os nossos desejos mais secretos e nossos medos ocultos. Deixamos os nossos corpos se redescobrirem no jogo da construção poética (MACHADO, 2008, 2017) e permitimos que o nosso inconsciente falasse através de 
imagens, pensando em anima. (BACHELARD apud FABRNI, in BAPTISTA; SERVERINO; ANDRÉ, 2015).

Tomando como referência as teorias do imaginário de Gilbert Durand (1998) e a psicologia arquetípica de Carl Gustav Jung (2012) pudemos lançar um novo olhar sobre os processos míticos e psíquicos vivenciados pelos intérpretes-criadores durante a criação do espetáculo "Gosto de Flor". Partindo das nossas mitologias pessoais (FEINSTEIN \& KRIPPNER, 1992) construímos uma dramaturgia de imagens, uma dramaturgia que emergiu de um processo guiado por imagens e que se manifesta em cena através delas.

Por fim, concluímos que o jogo da construção poética é uma excelente opção metodológica para se trabalhar os aspectos simbólicos da cena, bem como as dimensões ocultas do nosso inconsciente. O jogo da construção poética coloca o intérprete-criador como figura central na criação e organização da dramaturgia do espetáculo, e isso desencadeia uma proposição cênica autônoma, autoral e intimamente ligada ao saber corporal de cada indivíduo.

\section{REFERÊNCIAS}

ARAÚJO, Allan Phyllipe Gomes Cassemiro de. Entre a dor e o amor: a excitação do corpo sensível, as memórias e os afetos nos processos de criação cênica. Natal, RN: [s.n.], 2017. Dissertação de mestrado, UFRN.

DURAND, Gilbert. O imaginário: ensaio acerca das ciências e da filosofia da imagem. Rio de Janeiro: DIFEL, 1998. 
FABRNI, Verônica. Arte, Ciência e Descolonização. in BAPTISTA, Ana Maria Haddad. SERVERINO, Francisca Eleonora. ANDRÉ, Caminda Mendes. (org.). Artes, Ciências e Educação. São Paulo: BT Acadêmica, 2015.

FEINSTEIN, David \& KRIPPNER Stanley. Mitologia Pessoal: a psicologia evolutiva do self. São Paulo: Cultrix, 1992.

HADERCHPEK, Robson Carlos (org). Arkhétypos Grupo de Teatro: Encontros e Atravessamentos. Natal: Fortunella Editrice, 2017.

HUIZINGA, Johan. Homo Ludens: o jogo como elemento da cultura. São Paulo: Perspectiva, 2007.

JUNG, Carl Gustav. Os arquétipos e o inconsciente coletivo. Petrópolis: Vozes, 2012.

MACHADO, Lara Rodrigues. Danças no Jogo da Construção Poética. Natal: Jovens Escribas, 2017.

MACHADO, Lara Rodrigues. O Jogo da Construção Poética: Processo Criativo em Dança. Campinas, SP: [s.n.], 2008. Tese de doutorado, UNICAMP.

SANTOS. Inaicyra Falcão dos. Corpo e Ancestralidade: Uma Configuração Estética Afro-Brasileira. In Revista Repertório Teatro \& Dança no 24. Salvador: PPGAC/UFBA, 2015. p.79-85. 


\section{NOTAS}

i É ator, diretor, pesquisador e professor associado da Universidade Federal do Rio Grande do Norte (UFRN), onde atua no curso de licenciatura em Teatro e no Programa de Pós-Graduação em Artes Cênicas (PPGARC), do Departamento de Artes (DEART). Bacharel em Artes Cênicas, Mestre e Doutor em Artes pela Universidade Estadual de Campinas (UNICAMP), tendo realizado pesquisa de Pós-Doutorado na Universidade de Música e Artes Cênicas de Viena, Áustria (2015). Foi presidente da ABRACE - Associação Brasileira de Pesquisa e PósGraduação em Artes Cênicas (Gestão 2017-2018) e integrou o Comitê do Plano de Cultura da UFRN. É membro dos Grupos de Pesquisa: CIRANDAR, NACE e ÍMAN, e diretor do Arkhétypos Grupo de Teatro. E-mail: rob_hader@yahoo.com.br.

ii Graduada em Dança (1994), com Mestrado (2001) e Doutorado (2008) em Artes Cênicas pela Universidade Estadual de Campinas/SP (Unicamp). Professora Associada do Centro de Artes da Universidade Federal do Sul da Bahia (UFSB). Professora Colaboradora do Programa de Pós-graduação em Dança da Universidade Federa da Bahia (UFBA). Professora Colaboradora do Programa de Pós-graduação do Departamento de Artes da Universidade Federal do Rio Grande do Norte (UFRN). Líder do Grupo Interinstitucional de Pesquisa "Corpo e Ancestralidade" (UFBA). Pesquisadora do Grupo de Pesquisa "Poéticas do Corpo e Saberes Populares" (UFSB). Mestra pela Escola Brasileira de Capoeira. Área de interesse e atuação nos temas dança, cultura, sociedade, arte e capoeira.

iii O Arkhétypos é um Grupo de Teatro da Universidade Federal do Rio Grande do Norte (UFRN), vinculado ao Departamento de Artes, do Centro de Ciências Humanas, Letras e Artes. É coordenado por Robson Haderchpek, professor da Licenciatura em Teatro e do Programa de Pós-Graduação em Artes Cênicas da UFRN, e composto por estudantes e docentes desses cursos, além de contar com colaboradores de áreas afins. Desde sua criação, em 2010, o Grupo atua nas áreas da pesquisa e da extensão, desenvolvendo processos criativos e produzindo espetáculos teatrais que almejam estabelecer proximidade na relação entre a comunidade e o meio artístico-acadêmico. Produziu onze espetáculos, tendo sido tema de cinco projetos de pesquisa, dezessete trabalhos de conclusão de curso, sete dissertações de mestrado e uma tese de doutorado, além de também ser tema de dois livros, três capítulos de livro e vinte artigos científicos. Para maiores informações, pode-se consultar o livro Arkhétypos Grupo de Teatro: Encontros e Atravessamentos (2017) ou a página do Grupo na internet: https://arkhetyposgrupodet.wixsite.com/arkhetypos (acesso em: 24 de abril de 2020).

iv Em nossa sociedade contemporânea, machista, patriarcal e homofóbica, o amor é um sentimento geralmente associado a feminino; é o feminino que ama, é o feminino que cuida, é o feminino que se sacrifica por amor. Ao masculino é vedado o direito de sentir, os homens "não choram", não demonstram seus sentimentos, daí o nosso interesse de pesquisar o amor na perspectiva do masculino. Acreditamos que as Artes da Cena podem nos ajudar a desconstruir este modelo tóxico de masculinidade que assola o nosso tempo.

${ }^{\vee}$ Adotamos o termo intérpretes-criadores, pois este é o termo que a pesquisadora Lara Rodrigues Machado emprega com maior frequência em sua tese de doutorado e em seu livro

Robson Haderchpek - “Gosto de Flor”: Dramaturgia de Imagens e Mitologia Pessoal no Jogo da Construção Poética 
sobre o jogo da construção poética, mas entendemos o intérprete-criador também como ator, bailarino e/ou performer, conforme a ocasião.

vi Para Lara Machado, diretora do espetáculo "Gosto de Flor, o jogo da construção poética (2008) se dá partir de uma diálogo corporal entre os intérpretes-criadores, e como nós utilizamos as imagens como estímulos para a criação, elas ganharam forma através do nosso corpo. Se fossemos desenhistas, provavelmente as traduziríamos por meio de traços e cores, se fôssemos músicos essas imagens se materializariam através notas musicais.

vii Ginga, esquiva, finta, negativa, chamada, ataque e defesa.

viii O significado obscuro das imagens está associado ao pensamento noturno, próprio das artes, defendido por Bachelard (apud FABRNI, in BAPTISTA; SERVERINO; ANDRÉ, 2015) e às teorias do imaginário propostas por Durand (1998).

ix Às vezes quando passamos por um trauma emocional ou quando precisamos "esconder" nossas emoções, nós deixamos o lado racional do cérebro imperar e assim amenizamos a dor. Agimos com pragmatismo e objetividade, suprimindo os nossos sentimentos. Este é um mecanismo de defesa da nossa psique, mas para dissolvermos o trauma precisamos deixar que ele reverbere no nosso lado emocional também, senão ele viverá como um eterno fantasma, nos assombrado sempre que trocarmos no assunto.

× Uma das versões dessa história integra a dissertação de mestrado do intérprete-criador Allan Phyllipe Gomes Cassemiro de Araújo intitulada Entre a dor e o amor: a excitação do corpo sensível, as memórias e os afetos nos processos de criação cênica (2017) - Programa de PósGraduação em Artes Cênicas da UFRN.

Submissão: 14/05/2020

Aceite: $25 / 07 / 2020$

Robson Haderchpek - “Gosto de Flor”: Dramaturgia de Imagens e Mitologia Pessoal no Jogo da Construção Poética 